\title{
地形や地質の違いが天然ダムの堆積形状に 与える影響 \\ PREDICTION OF LANDSLIDE DAM FORMATION AFFECTED BY TOPOGRAPHICAL AND GEOLOGICAL CONDITIONS
}

\author{
原田 紹臣 1 - 小杉 賢一朗 2 - 里深 好文 3 - 水山 高久 4 \\ Norio HARADA, Ken'ichirou KOSUGI, Yoshifumi SATOFUKA and Takahisa MIZUYAMA \\ 1正会員 博 (工) 京都大学大学院農学研究科 ( $\bar{T} 606-8502$ 京都市左京区北白川追分町) \\ 2非会員 農博 京都大学大学院農学研究科 准教授（下 606-8502 京都市左京区北白川追分町） \\ 3 正会員 工博 立命館大学 教授（广525-8577 滋賀県草津市野路東1-1-1） \\ 4 正会員 農博 京都大学大学院農学研究科 教授（７６06-8502 京都市左京区北白川追分町）
}

\begin{abstract}
Landslide dams are caused by large-scale slope collapse. Predicting their failure is important because hazardous flooding may result downstream when landslide dams burst. Accurate prediction of a landslide-dam formation which means height and length via landslide maps that show two-dimensional figure but does not consider landslide depth is needed for a countermeasure against the sediment disaster caused by landslide dam. In this study, past landslide dam failures were investigated. Relationships between landslide dam formation and the topographical and geological characteristics of the region were established to improve landslide dam analysis for more accurate prediction of dams' structural integrity.
\end{abstract}

Key Words : Landslide dam, formation, topography, statistics, prediction

\section{1.はじめに}

大規模な地すべりや深層崩壊等に起因して形成された 天然ダムの決壊に関する研究は, 決壊に伴って発生する 下流域における洪水汇濫の防御等に対して重要であると 考えられる. 現在, 各地において調査された発生する可 能性の高い深層崩壊の存在寸る渓流が，公表されている 1)。また，全国において確認されている地すべり地が示 された地形分布図が公表されている2). 今後，新たに形 成される可能性のある天然ダムに対して，事前にこれら の情報を用いた決壊等の災害防止に備えた対策の検討が 望まれている1).ただし，これらの公表されている情報 は崩壊斜面の平面形状や閉塞地点における河道形状等で あり，斜面崩壊の深さや土塊の移動過程等が不明瞭なた め, 一般的に閉塞形状の予測は困難である。

天然ダム決壊に伴う洪水流出に関して，実験や解析モ デルを用いた検討等による小田ら ${ }^{3)}$, 高橋・中川 $\left.\right|^{4)}$, 里深

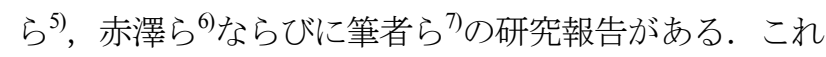
らの報告によると, 天然ダム形状の違いが決壊に伴い流 出する洪水流出過程に影響を与えることが示されている. なお，実験結果や過去の被害事例がそれぞれの解析モデ
ルを用いて再現されている例え゙゚, 7。しかしながら，これ らの研究は堆積後の天然ダム決壊を対象としており, 新 たに形成される天然ダム形状について検討する場合, 斜 面崩壊により移動する土塊が河道を閉塞する形状（天然 ダムの堆積形状）について，別途に予測する必要がある.

大規模な斜面崩壊等により形成される天然ダムの堆積 形状に関して, 解析モデルを用いた予測手法が提案され ている ${ }^{8,9)}$. 朗・中村 ${ }^{8}$ はNakamura et al. ${ }^{10)}$ により開発さ れたモデルに改良を加えて，大規模な斜面崩壊等による 移動土塊の流下や堆積過程を再現している. また, 里深 ${ }^{9}$ は土塊の運動に関して，ラグランジュ的に解析する手 法を考慮したモデルを用いて，同様に過去に発生した災 害事例を対象に再現している.ただし，これらのモデル の適用において, 適正なパラメータの設定に関寸る課題 がそれぞれ示唆されている. 一方, 高橋・匡 ${ }^{11)}$ は, 新た に形成される天然ダムの堆積形状に関して, 理論的考察 及び室内実験結果を用いた簡易な予測式を提案している. ただし，提案された予測式は理想的な土質条件に基づく ものであり, 過去の発生事例との比較による検証がなさ れていない. また，実施された実験結果と予測結果との 比較による検証において，更なる改善が示されている. 本研究では, 新たに形成される天然ダムの形状に関し 
て, 過去の発生事例 ${ }^{12}$ と既往の予測式 ${ }^{11)}$ で再現した值と の比較による既往予測式の妥当性検証，過去の事例 ${ }^{12)}$ 用いた天然ダムの形状に影響を与える因子の抽出及び抽 出された因子等を考慮した新たな予測式を示した. 最後 に, 斜面崩壊の規模を想定するため, 斜面崩壊の規模と 関係のある崩壊深さに関して，過去の発生事例を用いて 地質や誘因が崩壊深さに与える影響について分析した.

\section{2. 天然ダムの堆積形状に影響を与える因子の抽出}

\section{（1）天然ダムの堆積形状に関する既往予測式の検証}

既往予測式 ${ }^{11}$ に関して, 過去に発生した天然ダムの発 生事例 ${ }^{12)}$ との比較により既往予測式の妥当性を検証する. なお，既往報告によると移動土塊の土質条件や河床勾配 の違いを考慮した場合，天然ダムの堆積高及び堆積長は，

$$
\begin{aligned}
& L_{B}=\frac{W}{\cos \theta}+\frac{V \cos \theta}{2 B W} K \\
& K=\frac{\cos \theta}{\tan (\phi+\theta)}+\sin \theta+\frac{\sin (90+\phi)}{\sin (\phi-\theta)} \\
& D_{\max }=\frac{2 V}{B\left(L_{B}+L_{T}\right)}
\end{aligned}
$$

と表される ${ }^{11)}$. ここに, $L_{B}$ は天然ダムの堆積長（台形の 基底長 : 図-1）， $L_{T}$ は天然ダムの頂部長， $W$ は斜面崩壊 幅, Vは移動土塊量, $B$ は河道堰き止め幅, $D_{\max }$ は天然ダ 么の最大堆積厚， $\theta$ は河床勾配， $\phi$ は崩壊土砂の安息角 及び $K$ $\theta$ と $\phi$ の関数である.ここで，天然ダムの法肩 部は必ずしも明膫でないため, 天然ダムの形状を三角形 として仮定すると，

$$
\begin{aligned}
& V_{S C}=2(W / \cos \theta)^{2} B / K \\
& L_{B S C}=\frac{W}{\cos \theta}+\frac{V_{S C} \sin \theta}{2 B W} K \\
& L_{B}=\left(\frac{V}{V_{S C}}\right)^{1 / 2} L_{B S C}
\end{aligned}
$$

と表される ${ }^{11)}$.ここに, $V_{S C}$ は三角形として仮定した場
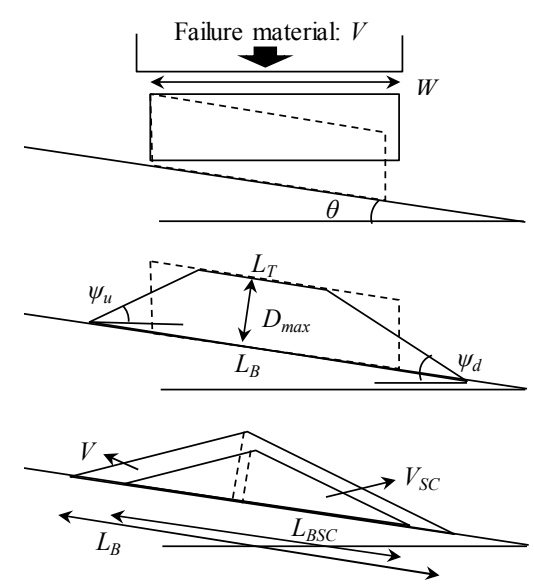

図-1＼cjkstart形成される天然ダムの形状に関する概念図
合の形成限界における土砂体積量, $L_{B S C}$ は三角形ダムが 形成される場合における限界の基底部長である.

ここで，水山ら ${ }^{12)} に よ り$ 整理された過去に発生した国 内における天然ダムの事例（61災害，168事例，ただし， 有効事例数 133事例) を対象に, 既往予測式(6)を用いて 算出した天然ダムの長さ (基底長) の計算值と実績值と の比較を図-2に示寸. 図-2に示されるとおり, 計算值と 実績値との相関は低く（相関係数 $r=0.16$ : 一般的に相 関係数 $r$ が0.7以上で相関が良いとされている），更な る改善が必要であると考えられる. なお，既往報告 ${ }^{111} に$ よると, 室内実験結果より河床勾配の違いは天然ダムの 形状にあまり影響を与えないことが指摘されている.

\section{（2）天然ダムの堆積形状に影響を与える因子の抽出}

天然ダムの堆積形状に関する新たな予測式を提案する ため, 過去の発生事例 ${ }^{(2)}$ 対象に統計解析手法を用いて 分析し, 天然ダムの堆積形状に影響を与える因子につい て抽出する. 過去に形成された天然ダムの形状について, 一般的に因子分析に用いられている多变量解析 (数量化 理論而類）手法例え゙ホ,13)を用いて分析した結果を図-3に示 寸. なお，数量化理論而類は因子がそれぞれのカテゴ リーに与える影響のパターンに基づいて因子とカテゴ リーについて数量化し，その関係性を図的表示（点間距 離の近接距離と相関性との関係）により分類する手法で ある. 図-3（上）に示されるとおり, 縦軸の変化と堆積 長 (Dam length) の長短, 横軸の変化と堆積高（Dam height）の高低との間にそれぞれ関係性が確認される. また, 天然ダム堆積長の長短と斜面崩壊幅 (Landslide width）の広狭との関係において，比較的に高い相関が 確認される。これは, 式(1)及び(5)の予測式において示 される関係と同じであり, 斜面崩壊地形の違いが堆積長 に影響を与えていることを示している. また, 堆積高の 高低と堆積幅（堰止め幅: Dam width）の広狭との関倸性 が確認される. 一方，図-3（下）に示されるとおり，天 然ダム形成の誘因 (豪雨: Heavy rain, 地震: Earthquake) や各地質の因子が縦軸（堆積高）及び横軸（堆積長）の 変化を示している平面図上において幅広く分散しており, これらの因子の違いが堆積形状に影響を与えていること が定性的にわかる.

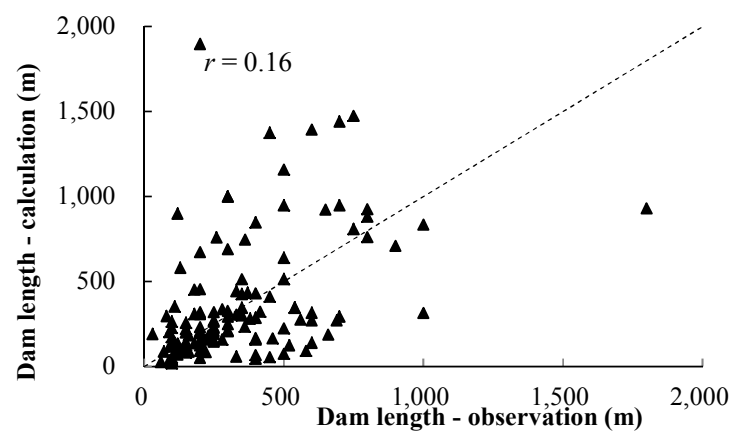

図-2 過去の天然ダム発生事例を用いた予測式の妥当性検証 
次に，数量化理論III類で定性的に整理された因子間の 関係性に関して，天然ダムの堆積高及び堆積長に対して それぞれの因子が影響を与えている程度について数量化
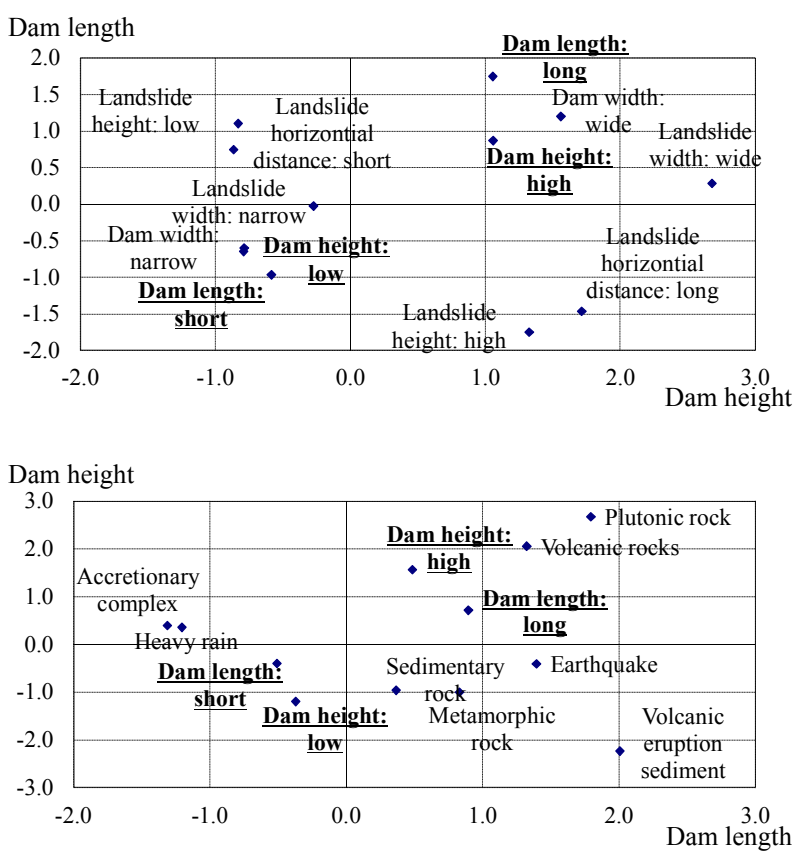

図-3 数量化理論而類を用いた天然ダムの堆積形状に関する因 子分析 (上 : 地形条件等に着眼，下：地質や誘因に着眼）

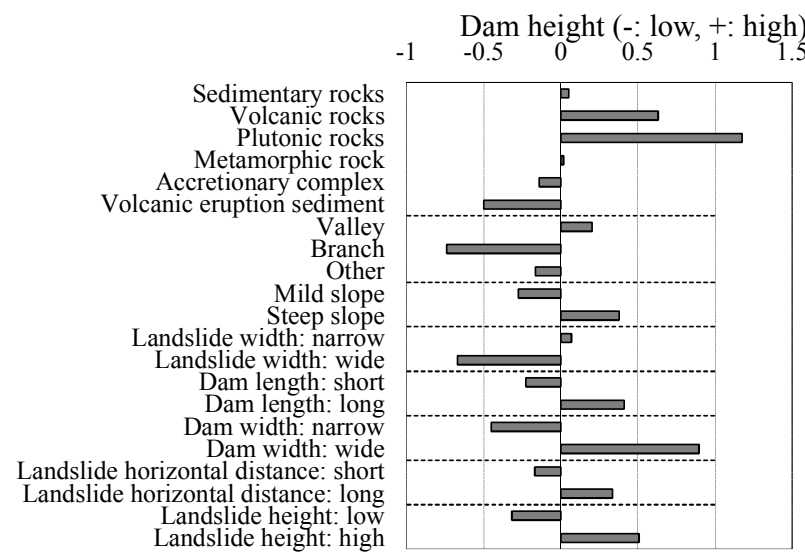

Dam length (-: short, +: long)

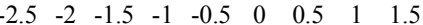

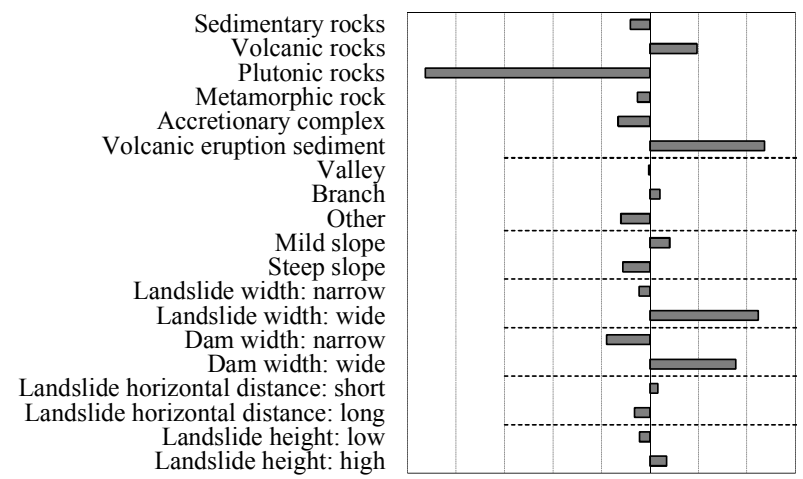

図-4 数量化理論I類を用いた天然ダムの堆積形状に関する因 子分析(上：堆積高を対象，下：堆積長を対象)
理論 II 類を用いて分析する. なお，数量化理論 II類は質 的な要因を用いて最適な外的基準の值を予測するための 手法であり，棒の長短がそれぞれの関係性の程度を示す。 数量化理論 II 類による分析結果を図-4（上 : 堆積高, 下 : 堆積長）に示す. 図-4（上）に示される堆積高に関 して, 深成岩 (Plutonic rock) や火山岩（Volcanic rock） 等の違いが堆積高に影響を与えているのがわかる。その 他として，堰止め形式（例えば，谷地形: Valley，支流合 流: Branch) や崩壊斜面勾配（崩壊高を水平距離で除し た值: Slope incline）の違いが堆積高に影響を与えている のがわかる. また，堆積長に関しても同様に地質（深成 岩や火山噴出物: Volcanic eruption sediment）の違いが堆 積長に影響を与えているのがわかる。これらの結果より， 斜面地形，天然ダム形成の誘因，河道幅（堰止め幅）， 堰止め形式ならびに地質の違い等が天然ダムの堆積形状 に影響を与えていることが明らかとなった。

\section{3. 天然ダムの堆積形状に関する予測式の提案}

前述の2.における数量化理論を用いた分析結果より, 公表されている情報例えば, 2)等を用いて天然ダムの形状

(堆積高及び堆積長) を予測できる可能性が示された. そこで，大規模な斜面崩壊等により形成される天然ダム の堆積形状に関して，過去における天然ダムの発生事例 を用いて分析し，簡易な予測式を新たに提案する.

\section{（1）堆積高に関する予測式の提案}

過去における天然ダムの発生事例 ${ }^{12)}$ を対象に，前述 2 . に示された天然ダムの堆積形状に影響を与えると推測さ れる因子を用いて，重回帰分析法により天然ダムの堆積 高に関する予測式を提案する．簡単のため，本研究では 谷地形を呈する閉塞（谷壁斜面の土砂移動）を対象とす る. 河道閉塞土砂の水平距離と比高に関する概念図を図 -5に，天然ダムの堆積形状に関する概念図を図-6にそれ ぞれ示す ${ }^{12)}$. 予測精度を高めるため变数減少法を用いて 説明変数を最適化し，天然ダム形成の誘因毎に応じたそ れぞれの予測式を示す．なお，地質の違いに応じたそれ ぞれの予測式に関する提案も考えられるが，簡単のため, 必要に応じて地質の違いを考慮するものとする.

重回帰分析法及び变数減少法を用いて詳細に分析した 天然ダムの堆積高は,

$$
H_{\text {earthquake or heavy rain }}=\alpha_{1} \cdot h_{1}+\beta_{1} \cdot l_{1}+\gamma_{1} \cdot w_{1}+\delta_{1} \cdot A_{1}
$$

と表される．ここに， $H_{\text {earthquake }}$ は地震により形成された 天然ダムの堆積高 $(\mathrm{m}), H_{\text {heavy rain }}$ は豪雨により形成さ れた天然ダムの堆積高 $(\mathrm{m}), h_{1}$ は土砂移動の頭部から 河床までの比高 $(\mathrm{m}), \quad l_{1}$ は土砂移動の頭部から河床 までの水平距離 $(\mathrm{m}), w_{1}$ は堰き止め幅（河道幅 $; \mathrm{m} ）$ ， $A_{1}$ は発生源 (崩壊斜面) 面積 $\left(/ 100,000 \mathrm{~m}^{2}\right)$ 及び $\alpha_{1}$, 

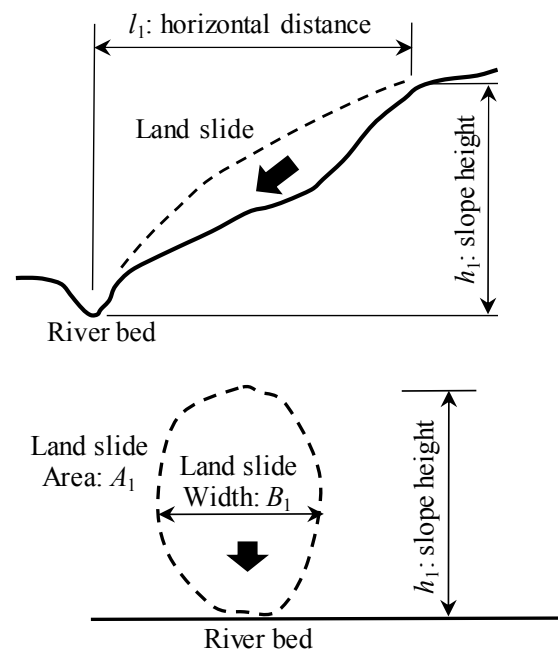

図-5 河道閉塞に二起因する斜面崩壊に関する概念図 ${ }^{12}$

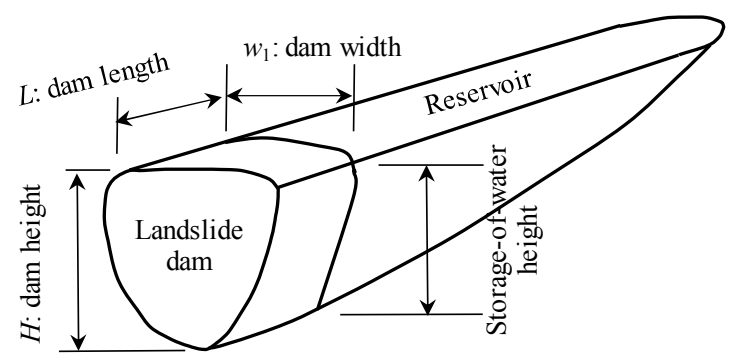

図-6 天然ダムの堆積形状に関する概念図 ${ }^{12)}$

表-1 誘因毎に応じた天然ダムの堆積高に関する予測式の係数

\begin{tabular}{|l|r|r|r|r|}
\hline & \multicolumn{1}{|c|}{$\alpha_{1}$} & \multicolumn{1}{c|}{$\beta_{1}$} & \multicolumn{1}{c|}{$\gamma_{1}$} & \multicolumn{1}{c|}{$\delta_{1}$} \\
\hline \hline Earthquake & 0.11 & 0.014 & 0.032 & 0.039 \\
\hline Heavy rain & 0.081 & 0.0039 & 0.063 & 0.35 \\
\hline
\end{tabular}

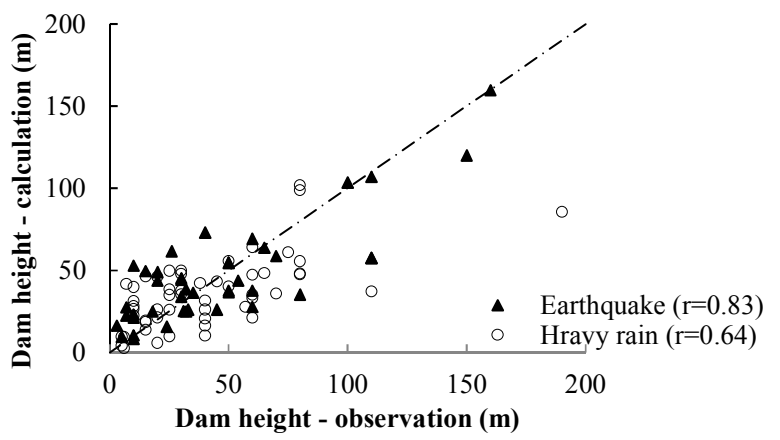

図-7 提案する天然ダム堆積高に関する予測式を用いた推定値 と実績值との比較（ただし，谷壁斜面の土砂移動）

$\beta_{1}, \gamma_{1}, \delta_{1}$ は誘因毎に応じた係数（表-1）である（図-5, -6）. 提案する天然ダムの堆積高に関した予測式(7)の 妥当性を検証するため, 過去の発生事例 ${ }^{12)}$ 対象にした 計算值(Calculation) と実績值(Observation)との比較を図-7 に示す. 図-7に示されるとおり，地震により形成された 天然ダムの堆積高は予測可能なことがわかった（相関係 数 $r=0.83: 0.7$ 以）. しかしながら, 豪雨により形成 された堆積高に関しては予測精度が低いことがわかった

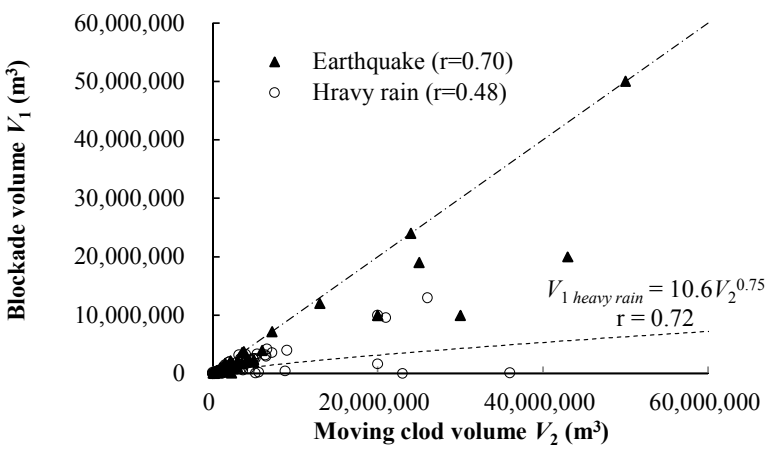

図-8 斜面からの移動土塊量と天然ダムの堆積土量との関係

(相関係数 $r=0.64: 0.7$ 未満）.この要因に関して以降に 考察する. 災害発生後の調査結果に基づいて推定された 崩壊斜面からの移動土塊量と天然ダムの堆積土量との関 係を図-8に示す. 図-8に示されるとおり，地震時の斜面 からの移動土塊量と堆積土量との関係はほぼ同じ傾向

(1:1の回帰直線上における相関係数 $r=0.7)$ であるが, 豪雨時の堰止土量は斜面からの移動土塊量に比べて顕著 に減少している（例えば，豪雨時における近似式 $V_{1}$ heavy rain）.これは，天然ダム堆積後に降雨や流水等により侵 食を受け，最終的に土量が減少したものと推測される. 一方, 既往研究 ${ }^{7)}$ より天然ダムの形状や湛水量の違い等 が決壊に伴って流出する洪水流出過程に影響を及ぼすこ とが指摘されている. 現時点では豪雨時における天然ダ ムの侵食過程等が明確でないため, 本研究では安全側で の検討となる地震時における堆積高を対象にした予測式 の適用を提案する. なお，予測式(7)により示されている 河道幅（堆積幅 $w_{1}$ ) が広くなるに伴って堆積高が高く なる傾向については，図-3及び図-4にも同様に示されて いるとおり興味深い点である.

\section{（2）堆積長に関する推定式の提案}

堆積高と同様に過去の形成事例 ${ }^{12)}$ を用いて，天然ダム の堆積長に関する簡易な予測式を提案する.

重回帰分析法及び変数減少法を用いて分析した天然ダ 么の堆積長は,

$$
L_{\text {earthquake orheavyrain }}=\alpha_{2} \cdot h_{1}+\beta_{2} \cdot l_{1}+\gamma_{2} \cdot w_{2}+\varepsilon_{2} \cdot B_{1}
$$

と表される.ここに， $L_{\text {earthquake }}$ は地震により形成された 天然ダムの堆積長 $(\mathrm{m}) ， L_{\text {heavy rain }}$ は豪雨により形成さ れた天然ダムの堆積長 $(\mathrm{m}), B_{1}$ は斜面崩壊幅 $(\mathrm{m})$ 及 び $\alpha_{2}, \beta_{2}, \gamma_{2}, \varepsilon_{2}$ は係数（表-2）である.

提案する堆積長に関した予測式(8)の妥当性を検証する ため, 過去の発生事例 ${ }^{12)}$ を用いた計算值と実績值との比 較を図-9に示す. 図-9に示されるとおり, 誘因毎に応じ て地形条件を考慮した天然ダムの堆積長に関する予測精 度はそれぞれ低いことがわかった（相関係数 $r: 0.7$ 未 満）。そこで，予測精度を向上させるため，新たに地質 の違いに応じた予測式をそれぞれ立案する. その際, 堆 


\section{表-2 誘因毎に応じた天然ダムの堆積長に関する予測式の係数}

\begin{tabular}{|l|r|r|r|r|}
\hline & \multicolumn{1}{|c|}{$\alpha_{2}$} & \multicolumn{1}{c|}{$\beta_{2}$} & \multicolumn{1}{c|}{$\gamma_{2}$} & \multicolumn{1}{c|}{$\varepsilon_{2}$} \\
\hline \hline Earthquake & 0.27 & -0.0043 & 0.98 & 0.0001 \\
\hline Heavy rain & 0.44 & 0.012 & 0.23 & 0.51 \\
\hline
\end{tabular}

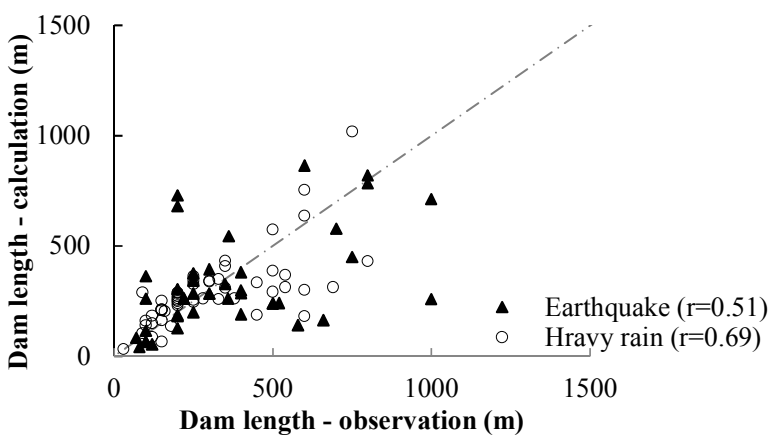

図-9 提案する天然ダム堆積長さに関する予測式を用いた推定 值と実績值との比較（ただし，谷壁斜面の土砂移動）

積過程において侵食の影響が比較的小さいと考えられる 地震により形成された天然ダムを対象とする.

地質の違い（火山噴出物, 火山岩, 堆積: Sedimentary rock，付加複合体: Accretionary complexes）を考慮した天 然ダムの堆積長（地震時）は，

$$
L_{\text {earthquake }}=\alpha_{3} \cdot h_{1}+\beta_{3} \cdot l_{1}+\gamma_{3} \cdot w_{1}+\varepsilon_{3} \cdot B_{1}
$$

と表される. なお， $\alpha_{3}, \beta_{3}, \gamma_{3}, \varepsilon_{3}$ は地質の違いに応じ た係数（表-3）である.

地質の違いを考慮した地震時における堆積長に関して 提案する予測式(9)の妥当性を検証するため, 過去の発生 事例を用いた計算值と実績值との比較を図-10に示す.

図-10に示されるとおり，地質の違いを考慮した地震に よる天然ダムの堆積長は予測可能なことがわかった（平 均相関係数 $r=0.84 ）$. なお，現時点においては情報が 不足しており，今後，対象事例や詳細な情報を加えた更 なる検討（例えば，詳細なダム形状予測）が望まれる.

\section{4. 天然ダムを形成させる斜面崩壊に関する分析}

前述の3. で示した天然ダム形状の推定式は，公表さ れている地すべり地形分布図 ${ }^{2}$ において示されている崩 壊斜面の平面形状や閉塞地点の河道地形等を用いた式で ある，ただし，天然ダムの対策について事前に検討する ためには，対象斜面の規模や崩壊深さについて事前に把 握しておくことが重要である。そこで，天然ダムを形成 させた斜面崩壊の事例 ${ }^{12)}$ 対象に統計解析手法を用いて, 地質の違い等が崩壊深さに与える影響について検討する。

斜面の崩壊事例を対象に統計解析を用いて分析した地 質の違いと崩壊深さとの関係を図-11に示す。また，崩 壊事例を対象に発生した斜面崩壊数を用いて加重平均し た地質毎の平均崩壊深さの一覧を表-4に示す．図-11及
表-3 天然ダムの堆積長に関する予測式における地質の違いに 応じた係数（ただし，地震時及び谷壁斜面の土砂移動）

\begin{tabular}{|l|r|r|r|r|}
\hline & \multicolumn{1}{|c|}{$\alpha_{3}$} & \multicolumn{1}{c|}{$\beta_{3}$} & \multicolumn{1}{c|}{$\gamma_{3}$} & \multicolumn{1}{c|}{$\delta_{3}$} \\
\hline \hline Volcanic eruption sediment & 0.73 & 0.58 & 0.98 & 0.001 \\
\hline Volcanic rock & 0.10 & -0.12 & 0.98 & 0.63 \\
\hline Sedimentary rock & -0.29 & 0.087 & 1.5 & 0.0001 \\
\hline Accretionary complexes et al. & -4.1 & 2.2 & -0.74 & 1.4 \\
\hline
\end{tabular}

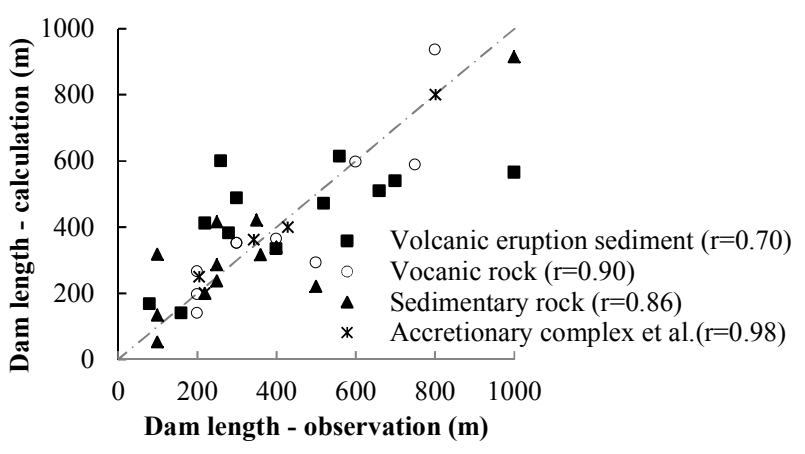

図-10 提案する地質の違いを考慮した天然ダム堆積長さに関 する予測式を用いた推定値と実績值との比較（ただし， 地震時及び谷壁斜面の土砂移動)

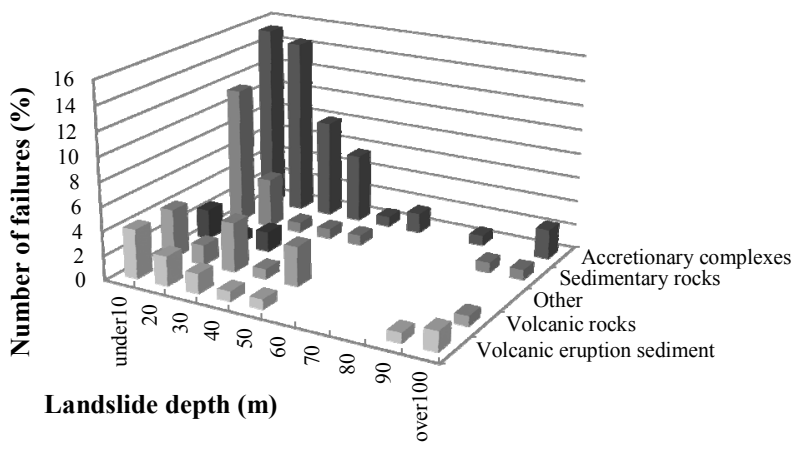

図-11 地質の違いを考慮した斜面崩壊深さと崩壊数との関係

表-4 地質毎の平均崩壊深さ（崩壊事例を用いた平均值）

\begin{tabular}{|c|c|}
\hline Geology type & Weighted average depth $(\mathrm{m})$ \\
\hline \hline Volcanic eruption sediment & 37 \\
\hline Volcanic rocks & 32 \\
\hline Accretionary complexes & 28 \\
\hline Sedimentary rocks & 23 \\
\hline Other & 18 \\
\hline
\end{tabular}

び表-4に示されるとおり，火山地域における地質（火山 噴出物や火山岩）の崩壊深さは，他の地質に比べて深い ことがわかった. 参考に, 天然ダム形成の誘因の違いと 崩壊深さとの関係を図-12に示す.さらに，崩壊事例を 用いて同様に加重平均した誘因毎の平均崩壊深さの一覧 を表-5に示す. 図-12及び表-5に示されるとおり, 誘因 の違いは崩壊深さにあまり影響を与えていないことがわ かった（相関係数 $r=0.93 ）$. ただし，地震時における 斜面崩壊深さは豪雨時に比べて深い傾向であることが示 された．今後，更なる検証が望まれる. 


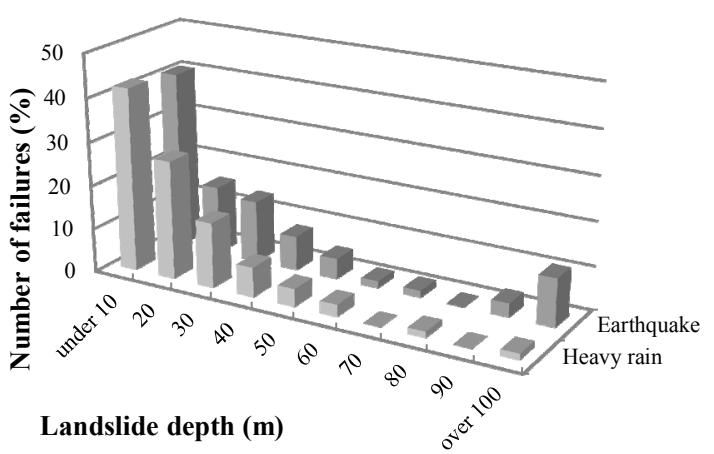

図-12 誘因の違いを考慮した斜面崩壊深さと崩壊数との関係

表-5 誘因毎の平均崩壊深さ（崩壊事例を用いた平均値）

\begin{tabular}{|c|c|}
\hline Trigger type & Weighted average depth $(\mathrm{m})$ \\
\hline \hline Earthquake & 33 \\
\hline Heavy rain & 23 \\
\hline
\end{tabular}

\section{5. おわりに}

公表されている地すべり地形分布図や地質等の情報を 用いて大規模な斜面崩壊等により新たに形成される天然 ダムの決壊に伴う洪水汇濫等について事前に検討するた め, 本研究では天然ダムの発生事例を用いて天然ダムの 堆積形状に関する簡易な予測式の提案及び地質や誘因の 違いが斜面崩壊深さに与える影響について分析した。

本研究により得られた成果を, 以下に要約する.

1) 理論的考察及び室内実験結果を用いて提案された天 然ダムの堆積形状に関する既往予測式を対象に，そ の適用性について天然ダムの発生事例を用いて検証 した．計算值と実績值との比較によると，提案され た予測式は更なる改善が必要であることがわかった。 ただし，過去の発生事例を対象に本研究で分析した 結果によると，既往予測式で考慮されている斜面崩 壊幅が堆積長に影響を与えていることが分かった.

2) 過去の事例を対象に数量化理論（II類，III類）を用 いて分析し，天然ダムの堆積形状に影響を与える因 子について考察した．分析結果によると，斜面崩壊 の地形，天然ダム形成の誘因，河道幅（堰止め幅）， 堰止め形式ならびに地質の違い等が形成される天然 ダムの堆積形状に影響を与えていることが分かった。

3) 天然ダムの発生事例を対象に重回帰分析法及び変数 減少法を用いて詳細に分析し，想定される斜面崩壊 等により形成される天然ダムの堆積形状（堆積高及 び堆積長）に関する簡易な予測式を新たに示した。 今後，詳細な形状予測に関する研究が望まれる.

4) 天然ダムを形成させた斜面の崩壊事例を対象に統計 解析を用いて地質の違いと崩壊深さとの関係につい て分析したところ，火山地域における地質（火山噴
出物や火山岩）の斜面崩壊深さは他の地質（例えば, 堆積岩）に比べて深いことがわかった。一方，天然 ダム形成の誘因（豪雨，地震）の違いは斜面崩壊深 さにあまり影響を与えないことが示唆された。

謝辞：本研究を進めるにあたり，一般社団法人 砂防フ ロンティア整備推進機構の井上公夫氏から助言を頂いた. ここに記して謝意を表す。

\section{参考文献}

1) 国土交通省 : 深層崩壊に関する渓流(小渓流)レベルの調查に ついて, http://www.mlit.go.jp/report/press/mizukokudo03_hh 000552.html (2014/9/20_check), 2012.

2) 防災科学技術研究所 : 地すべり地形分布図データベース, http://lsweb1.ess.bosai.go.jp/pdfview/index.html (2014/9/20_check), 2013.

3) 小田 晃・水山高久 ・宮本邦明 : 短時間渓流閉塞における堆 積形状と決壊時のピーク流出量, ハイドログラフについて, 水工学論文集, Vol.53, pp.691-696, 2009.

4) 高橋 保, 中川 一: 天然ダムの越流決壊によって形成され る洪水・土石流のハイドログラフ, 水工学論文集, Vol.37, pp.699-704, 1993.

5) 里深好文, 吉野弘祐, 水山高久, 小川紀一郎, 内川龍男, 森 俊男: 天然ダムの決壊に伴う洪水流出の予測手法に関する研 究，水工学論文集，Vol.51,pp.901-906, 2007.

6) 赤澤史顕, 池田亮和, 里深好文 : 天然夕゙ム越流決壊に伴う流 出流量変動に関する研究, 土木学会論文集B1(水工学),Vol.70, No.4, pp.I_1027-I_1032, 2014.

7) Harada, N., Akazawa, F., Hayami, S. \& Satofuka, Y.: Numerical simulation of landslide dam deformation caused by erosion, Advances in River Sediment Research, ISBN 978-1-138-00062-9, pp. 1107-1116, 2013.

8) 朗 显華，中村浩之 : 黄土地すべりのすべり面形状の特性と 崩土の拡散範囲の予測，地すべり，Vol. 35-1，pp.9-18，1998. 9) 里深好文 : ハイブリッド土石流モデルによる平成 15 年水俣市 集川の土石流に関する再現計算, 水工学論文集, Vol.48, pp. 925-930, 2004.

10) Nakamura, H., Tsunaki, R. \& Ishihara, S.: Simulation model for debris movement of landslides, Proceedings of the Japan-China Symposium on Landslides and Debris Flows, Niigata, pp.81-86, 1989.

11) 高橋 保, 匡 尚富 : 天然ダムの決壊による土石流の規模 に関する研究, 京都大学防災研究所年報, Vol.31, B-2, pp.601-615, 1988.

12) 水山高久, 森 俊勇, 坂口哲夫, 井上公夫 : 日本の天然夕゙ 厶と対応策, 古今書院, pp.4-11, 2011.

13) 平田貴紅子・杉尾 鉄 : 数量化理論第III類による九州一級 河川の性格の類型化, 土木学会 年次学術講演会, Vol.63, pp.7-195-7-196, 2008.

(2014. 9. 30受付) 